\title{
45. TEXTURAL AND COMPOSITIONAL CHARACTERS OF EIGHT SAMPLES FROM HOLES 652A AND 654A (LEG 107, TYRRHENIAN SEA) ${ }^{1}$
}

\author{
Giuseppe Cavarretta, ${ }^{2}$ Giacomo Civitelli, ${ }^{2}$ Enzo Francaviglia, ${ }^{3}$ and Goffredo Mariotti ${ }^{4}$
}

\begin{abstract}
Upper Miocene sediments from two holes located in the Sardinian continental margin were analyzed to provide compositional data suitable for depicting their depositional environment and for paleogeographic reconstructions.

Samples from Hole $652 \mathrm{~A}$ are sterile, calcareous-sandy siltstones which are rather similar considering their compositional parameters. They are markedly different from the silty-sandstones of Hole 654A which also show a high variability between them, particularly in terms of fossil and glauconite content (Sample 107-654A-45R-06, 066-068 cm), or mineralogical and chemical composition (Sample 107-654A-47R-01, 076-078 cm).
\end{abstract}

\section{INTRODUCTION}

The paper discusses textural, compositional, and stratigraphic characters of eight samples: one from Core 107-654A-45R, one from Core 107-654A-47R, three from Core 107-652A-73R, and three from Core 107-652A-74R. The two holes were drilled within Leg 107, Tyrrhenian sea, on the Sardinian continental margin. Site 654 is the northernmost one in the whole Leg 107, while Site 652 rests upon one of the easternmost blocks of the margin, at the boundary of the western edge of the Vavilov basin.

The two holes crossed a sedimentary sequence whose bottom consists of continental lithofacies (lacustrine in Hole 652A and subaerial in 654A), overlain by increasingly marine ones. The latter are represented by planktonic-foraminifers calcareous oozes, already in the upper Tortonian-lower Messinian in Site 654, and Pliocene in Site 652.

In particular, Hole 107-654A crossed $483 \mathrm{~m}$ of deposits, which record the rise and the evolution of the continental margin. The basal $60 \mathrm{~m}$ house a conglomerate of pebbles embedded in a red matrix (Sample 107-654A-47R-01, 076-078 cm). Then the sequence consists of green, glauconitic sandstones (Sample $107-654 \mathrm{~A}-45 \mathrm{R}-06,066-068 \mathrm{~cm}$ ) and, toward the top, of calcareous oozes, rich in marine fossils of upper Tortonian-basal Messinian age. The remaining Messinian is made up by fine, pyriterich, laminated sediments and then by massive gypsum beds and sterile gypsiferous marls. The Pliocene and Pleistocene mark the return of a pelagic environment.

Hole $652 \mathrm{~A}$ is $721 \mathrm{~m}$ deep. The 530 -m-thick, pre-Pliocene sequence exhibits highly consolidated sandstones at its base and subsequently marls. The dominant part of the sequence holds fine-grained, thin-stratified, sterile sediments, which are rich in sulfates. The sediments are occasionally varved and contain a single, interleaved, coarse level. The sequence contains frequent microtectonic structures and synsedimentary disturbances, which evidence seafloor instability. All of the sequence, of likely Messinian age, must have deposited in a lacustrine environment. The Pliocene and Pleistocene sediments are of pelagic environ-

\footnotetext{
${ }^{1}$ Kastens, K. A., Mascle, J., et al., 1990. Proc. ODP, Sci. Results, 107: College Station, TX (Ocean Drilling Program).

2 Centro di Studio per la Geologia dell'Italia Centrale, del (N.R.) Dipartimento di Scienze della Terra, Universita "La Sapienza," P. le Aldo Moro 5, 00185 Rome, Italy.

${ }^{3}$ Istituto per le Tecnologie Applicate ai Beni Culturali del C.N.R., 00010 Montelobretti, Rome, Italy.

${ }^{4}$ Dipartimento di Scienze della Terra, Universita "La Sapienza," P. le Aldo Moro 5, 00185 Rome, Italy.
}

ment. (Curzi et al., 1987; Rehault et al., 1987; Robertson et al., 1987; Sartori et al., 1987; Tisseau et al., 1987).

\section{SAMPLES AND METHODS}

The analytical study was initially conducted on thin sections, parallel or normal to the resin-embedded sediment lamination planes. From each sample, two homogeneous portions were collected. The first was disaggregated by combined $\mathrm{H}_{2} \mathrm{O}_{2}$ and desogene treatment, yielding an assemblage of individual clasts which was used for compositional and morphoscopic studies via EDS-equipped SEM and for micropaleontological analyses. The second portion, mechanically reduced to approximately less than $5 \mu \mathrm{m}$, was used for X-ray diffractometry and thermogravimetry. Chemical analyses of major and minor elements were carried out by means of X-ray fluorescence spectrometry.

\section{DISCUSSION OF RESULTS}

\section{Hole 107-652A}

Core 107-652A-73R represents the 692.2-701.9 m interval of Hole 652A. Such interval encompasses dark-gray, sandy-calcareous oozes, sandy silts, and muds. The sandy silts are generally highly consolidated, massive, or poorly laminated. However, thin, graded levels and slumps are observed (see Kastens, Mascle, et al., 1987). Three samples were investigated (Pl. 1-1, -2, -3).

Sample 107-652A-73R-01, 107-109 cm, is a gray, highly consolidated, calcareous-sandy siltstone, with thin vegetal laminae and abundant matrix. Its total carbonate content is $36 \%$. It has a higher dolomite component than all the other samples (Pl. 19). Its skeletal fraction is highly heterometric. A primary mode, corresponding to class $30-60 \mu \mathrm{m}$, and a secondary one (100-200 $\mu \mathrm{m})$ can be identified. The granules are lithoclastic and monomineral. The former hold abundant fragments of calcareous rocks (both micritic and calcarenitic) and of low-grade metamorphic rocks, while chert fragments are more sporadic. Among the monomineral granules, the most numerous ones are quartz with both undulated (the most frequent) and straight-line extinction. Quartz is always found in poorly rounded forms. Calcite is both detrital and in small idiomorphic crystals. Rhombohedral carbonate forms are also common, evidenced also by X-rays. Phyllosilicates, namely muscovite and biotite, often altered to chlorite or oxidized, acid plagioclases, and potassic feldspars are abundant. Glauconite, instead, is rare. Iron oxides and hydroxides are a frequent occurrence.

SEM-EDS analyses showed abundance not only of calcite and dolomite but also of magnesian calcite. Quartz, quantitatively dominant in the fractions ranging from 100 to $200 \mu \mathrm{m}$ is characterized by poorly rounded forms and is often polycrystal- 
line. Some granule surfaces exhibit triangular dissolution cavities containing minute, idiomorphic calcite crystals (approximately $10 \mu \mathrm{m}$ ) which might be the record of incipient cementation or cement relics (Pl. 1-10).

Sample 107-652A-73R-02, 049-052 cm lithologically consists in a gray, highly consolidated, calcareous-silty sandstone, with a total carbonate content of $34 \%$. It is very similar to the previous sample, from which it can be discriminated by having a slightly higher granule concentration and then a lower matrix amount. Additionally, its skeleton displays a coarser grain size $(300-400$ $\mu \mathrm{m})$, which is not encountered in the previous sample. From the compositional standpoint, the few observable differences are: greater frequency of lithoclasts, fragments of both metamorphic and marly rocks; occasional heavy minerals (garnet, apatite, monoclinic pyroxene); and smaller dolomite content.

Sample 107-652A-73R-03, 043-046 cm, is a gray, highly consolidated, calcareous-sandy siltstone with abundant matrix and total carbonate content of $36 \%$. Its skeletal fraction is finer in comparison with the two above samples. Generally, its coarsest granules do not exceed $100 \mu \mathrm{m}$. A weak lamination can be observed, evidenced by iso-oriented phyllosilicates. Its composition does not substantially depart from the one of the other samples from this core. Its mineralogy is almost exclusively represented by quartz with abundant polycrystalline forms and by calcite (magnesian calcite is frequent); small dolomite rhombohedra are widespread. Feldspars are subordinate. Chlorite (from biotite alteration) and glauconite are observed.

Core 107-652A-74R corresponds to the 701.9-710.5 m interval, whose top portion features gray, calcareous-sandy oozes and sandy silts with convolute laminations and graded levels. Toward the bottom, gray, calcareous oozes with subordinate, laminated sandy levels dominate. In its lowest portion, some thin anhydrite levels are encountered (see Kastens, Mascle, et al., 1987). Three samples were investigated (Plate 1-4, -5, -6).

Sample 107-652A-74R-02, 117-119 cm, is a gray, well-consolidated, calcareous-sandy siltstone, with evident lamination and grading and a total carbonate content of $34 \%$. Its coarsest levels consist of packed granules (size $60-70 \mu \mathrm{m}$ ) in a poor matrix. Its finer granules vary in size between 10 and $30 \mu \mathrm{m}$ and are dispersed in an abundant matrix, also rich in iron compounds. The dominant mineralogic species is calcite, often magnesian and associated with dolomite. Quartz is subordinate but always abundant and poorly rounded. Feldspars are frequent. Muscovite, biotite, glauconite, and alteration chlorite are also present.

Sample 107-652A-74R-04, 105-107 cm, lithologically, is a gray, consolidated, calcareous siltstone with evident lamination and abundant matrix. Its skeletal fraction comprises averagesized granules $(20-40 \mu \mathrm{m})$. From the compositional viewpoint, it is similar to the previous sample, except for a higher carbonate fraction $(41 \%)$.

Sample 107-652A-74R-CC, 007-009 cm, is a gray, well-consolidated, fine, calcareous siltstone with a total carbonate content of $27 \%$. Its matrix is abundant and its skeleton includes roughly $20-30$ micrometer-sized granules. It is clearly graded and laminated. Lamination is evidenced by the oriented distribution of iron oxides and phyllosilicates. Some laminae are discontinued and deformed, likely pointing to post-depositional structures generated by bioturbation. In terms of composition, no significant differences are noted with respect to the two samples from the same core. Garnet granules are sporadically observed.

\section{Hole 107-654A}

The two samples from this hole, the first from Core 107$654 \mathrm{~A}-45 \mathrm{R}$ and the second from Core 107-654A-47R, usually have structural and compositional characters which deviate from those observed in Hole 652A.
Core 107-654A-45R has in its upper portion (approximately $7 \mathrm{~m}$ ) a nannofossil-rich chalk, which passes to glauconitic sands toward the bottom. The chalk is highly disturbed and holds abundant foraminiferal and molluscan fragments. The glauconitic sands are rich in matrix and also contain scattered pebbles, more frequent at the top, which give rise to a mild inverse grading (see Kastens, Mascle, et al., 1987). The single sample available (107-654A-45R-06, 066-068 cm) was, collected from the sandy interval (Pl. 1-7). This is a gray, poorly compact, calcareous sandstone, with abundant matrix and a total carbonate content of $34 \%$. The texture is isotropic. Also the phyllosilicates do not have any iso-orientation. The inorganic skeletal fraction is highly heterometric and consists of lithoclasts and monocrystalline granules equally abundant. The lithoclasts, whose maximum size is around $2 \mathrm{~mm}$, are dominated by fragments of lowgrade metamorphic rocks. Among the granules, glauconite (particularly class $300-400 \mu \mathrm{m}$ ) is very frequent: it occurs in small globular masses, often grown inside the foraminiferal chambers, with green-tone pleochroism, low birefraction, and various degrees of evolution. Quartz is well represented (average size 100$200 \mu \mathrm{m}$ ); its forms are poorly rounded (the SEM discloses small conchoidal fractures with very sharp edges). Feldspars and phyllosilicates (muscovite and biotite) are subordinate. Among the heavy minerals are garnet, kyanite, and apatite.

The sample shows a fossil assemblage almost exclusively consisting of foraminifers. Nevertheless, rare ostracode valves and even rarer echinoid fragments are discernible. Among the foraminifers, generally well preserved, planktonic ones dominate over benthic ones and are characterized by Globorotalia suterae, G. acostaensis, Globigerinoides g. quadrilobatus, Globigerina nephentes, G. cf. woodi, and Orbulina. Without Globorotalia conomiozea, $G$. mediterranea, etc., the presence of the abovementioned forms suggests that the sediment is of upper Tortonian age, Globorotalia acostaensis acostaensis zone, Globorotalia suterae subzone (D'Onofrio et al., 1975).

Core $107-654 \mathrm{~A}-47 \mathrm{R}$ yielded slightly over $1 \mathrm{~m}$ of material, consisting in a plastic mix having pebbles of varying granulometry and lithology and from angular to subcircular morphology (see Kastens, Mascle, et al., 1987).

Sample 107-654A-47R-01, 076-078 cm (Pl. 1-8), is a reddish, poorly compact sandstone with abundant matrix, and with $11 \%$ carbonate content. The most abundant granules are represented by elongated but nonoriented lithoclasts of metamorphic rocks, maximum size 400-500 $\mu \mathrm{m}$. Among the monomineral granules, quartz is the most abundant. In some instances, quartz shows moderate signs of residence in an aqueous environment, evidenced by smooth but poorly rounded morphologies. Chlorite, biotite, and muscovite are frequent. Feldspars and calcite are subordinate. Gypsum is more occasional. Among the heavy minerals are garnet and tourmaline. Oxidized incrustations and reddish patinas are commonly observed on the granules of likely continental origin. Some internal casts of small planktonic foraminifer chambers are also encountered.

\section{CHEMICAL COMPOSITION}

Major and trace element chemistry of the eight samples analyzed is reported in Table 1 . $\mathrm{SiO}_{2}, \mathrm{Al}_{2} \mathrm{O}_{3}, \mathrm{CaO}$, and loss of ignition (LOI) account for over $85 \%$ of the total in all the samples with the exception of Sample 107-654A-47R-01, 076-78 cm, in agreement with a mineralogy where quartz, calcite, phyllosilicates, and feldspars are dominant. $\mathrm{Fe}_{2} \mathrm{O}_{3}$ is bound both to phyllosilicates and oxides-hydroxides diffused in some of the samples; homogeneity of $\mathrm{Na}_{2} \mathrm{O}$ values in all samples is related to similar plagioclase contents whilst the variance in $\mathrm{K}_{2} \mathrm{O}$ is more dependent on the relative abundance of phyllosilicates. The trace elements show ranges of values as might be expected from marine sediments, with chlorine, strontium, and barium partic- 
Table 1. Major $(\mathbf{w t} \%)$ and trace $(\mathrm{ppm})$ elements chemistry. ${ }^{\mathrm{a}}$

\begin{tabular}{|c|c|c|c|c|c|c|c|c|}
\hline Sample & 1 & 2 & 3 & 4 & 5 & 6 & 7 & 8 \\
\hline $\mathrm{SiO}_{2}$ & 42.87 & 43.25 & 44.01 & 42.80 & 34.35 & 44.64 & 37.52 & 49.96 \\
\hline $\mathrm{Al}_{2} \mathrm{O}_{3}$ & 7.32 & 7.65 & 7.61 & 8.74 & 11.46 & 12.13 & 7.78 & 18.31 \\
\hline $\mathrm{Fe}_{2} \mathrm{O}_{3}$ & 3.94 & 3.36 & 3.60 & 4.06 & 5.29 & 5.23 & 6.42 & 7.45 \\
\hline $\mathrm{MnO}$ & 0.15 & 0.12 & 0.11 & 0.13 & 0.22 & 0.11 & 0.07 & 0.08 \\
\hline $\mathrm{MgO}$ & 4.00 & 2.33 & 2.32 & 3.24 & 3.47 & 3.78 & 2.13 & 2.55 \\
\hline $\mathrm{CaO}$ & 17.43 & 19.97 & 19.12 & 17.26 & 18.39 & 12.86 & 21.80 & 5.45 \\
\hline $\mathrm{Na}_{2} \mathrm{O}$ & 1.34 & 1.45 & 1.40 & 1.52 & 1.27 & 1.43 & 1.21 & 1.66 \\
\hline $\mathrm{K}_{2} \mathrm{O}$ & 1.15 & 1.20 & 1.22 & 1.37 & 1.54 & 2.02 & 2.26 & 3.64 \\
\hline $\mathrm{TiO}_{2}$ & 0.33 & 0.34 & 0.35 & 0.40 & 0.42 & 0.58 & 0.34 & 0.87 \\
\hline $\mathrm{P}_{2} \mathrm{O}_{5}$ & 0.05 & 0.05 & 0.05 & 0.06 & 0.09 & 0.07 & 0.06 & 0.08 \\
\hline LOI & 21.42 & 20.28 & 20.21 & 20.42 & 23.50 & 17.15 & 20.41 & 9.95 \\
\hline S & 82 & 89 & 78 & 137 & 195 & 212 & 341 & 52 \\
\hline $\mathrm{Cl}$ & 1491 & 1593 & 1532 & 1879 & 1118 & 2047 & 1535 & 1336 \\
\hline $\mathrm{Nb}$ & 3 & 8 & 6 & 10 & 18 & 13 & 5 & 19 \\
\hline $\mathrm{Zr}$ & 73 & 89 & 78 & 118 & 95 & 105 & 67 & 173 \\
\hline $\mathrm{Y}$ & 22 & 24 & 20 & 29 & 32 & 33 & 18 & 47 \\
\hline $\mathrm{Sr}$ & 206 & 315 & 311 & 261 & 255 & 202 & 456 & 124 \\
\hline $\mathrm{Rb}$ & 45 & 48 & 47 & 56 & 49 & 83 & 82 & 140 \\
\hline $\mathrm{Zn}$ & 54 & 45 & 54 & 65 & 63 & 65 & 116 & 122 \\
\hline $\mathrm{Ni}$ & 85 & 84 & 88 & 83 & 127 & 89 & 80 & 91 \\
\hline V & 63 & 63 & 58 & 69 & 62 & 121 & 66 & 154 \\
\hline $\mathrm{Ba}$ & 638 & 731 & 574 & 111 & 502 & 168 & 186 & 464 \\
\hline $\mathrm{Th}$ & 7 & 3 & 3 & 2 & 6 & 6 & 6 & 9 \\
\hline $\mathrm{Pb}$ & 10 & 4 & 2 & 6 & 15 & 14 & 6 & 10 \\
\hline $\mathrm{Cu}$ & 0 & 0 & 24 & 0 & 15 & 2 & 0 & 33 \\
\hline $\mathrm{Ce}$ & 21 & 0 & 25 & 42 & 0 & 44 & 33 & 65 \\
\hline $\mathrm{Nd}$ & 4 & 20 & 20 & 22 & 0 & 32 & 14 & 51 \\
\hline $\mathrm{La}$ & 20 & 11 & 26 & 25 & 11 & 20 & 21 & 51 \\
\hline
\end{tabular}

a Sample numbers: $1=107-652 \mathrm{~A}-73 \mathrm{R}-01,107-109 \mathrm{~cm} ; 2=107-652 \mathrm{~A}-73 \mathrm{R}-02,49-52 \mathrm{~cm} ; 3=107$. 652A-73R-03, 43-46 cm; 4 = 107-652A-74R-02, 117-119 cm; $5=107-652 \mathrm{~A}-74 \mathrm{R}-04,105-107 \mathrm{~cm}$; $6=107-652 \mathrm{~A}-74 \mathrm{R}-\mathrm{CC}, 7-9 \mathrm{~cm} ; 7=107-654 \mathrm{~A}-45 \mathrm{R}-06,66-68 \mathrm{~cm} ; 8=107-654 \mathrm{~A}-47 \mathrm{R}-01,76-78$ $\mathrm{cm}$.

ularly abundant. As in the case of major elements, Sample 107654A-47R-01, 076-078 cm stands out, since most of its minor elements content is at the extremes of the ranges observed in this work.

The linear correlation coefficients (R) reported in Table 2 show: (1) silica variability is mainly dependent on quartz abundance and therefore shows limited correlations; (2) a sharp negative correlation between $\mathrm{Al}$ and $\mathrm{Ca}$ which is related mainly to phyllosilicate/carbonate ratio; (3) alumina shows high correlation coefficients with $\mathrm{Ti}, \mathrm{K}$, and with trace elements such as $\mathrm{Rb}$, $\mathrm{Nb}, \mathrm{Y}, \mathrm{Nd}, \mathrm{Zr}, \mathrm{Ce}$, and $\mathrm{V}$, which are thought to be bound to the phyllosilicate structures. The thermogravimetric determinations showed that LOI, on the average, is due to about $5 \%$ water and $15 \% \mathrm{CO}_{2}$, thereby justifying the high correlation between LOI and $\mathrm{Ca}$. Metallic elements such as $\mathrm{Mn}, \mathrm{Zn}, \mathrm{Ni}$, and $\mathrm{Pb}$ do not display any significant correlation: it is suggested that they are related to some very minor accessory components.

To check the chemical affinity in terms of major elements between the samples from the three cores, an average linkage cluster analysis was carried out (see Fig. 1). Sample 107-654A$47 \mathrm{R}-01,076-078 \mathrm{~cm}$, clearly stands out with respect to all others: in fact it represents the only one with some continental features. Samples from Core 107-652A-73R display a very small "average distance," in agreement with their compositional homogeneity. Instead, a higher variance was found between the three samples from Core 107-652A-74R; as can be inferred from the relative abundances of $\mathrm{SiO}_{2}, \mathrm{Al}_{2} \mathrm{O}_{3}$, and $\mathrm{CaO}$, such variance is reasonably related to different calcite/quartz/phyllosilicates ratios.

\section{REFERENCES}

Curzi, P., Sartori, R., Sprovieri, R., et al., 1987. La crociera 107 della "Joides Resolution" (Ocean Drilling Program) nel mar Tirreno: risultati preliminari. Boll. Soc. Geol. Ital., 106:93-98

D'Onofrio, S., Giannelli, L., Iaccarino, S., Morlotti, E., Romeo, M., Salvatorini, G., Sampo, M. and Sprovieri, R., 1975. Planktonic foraminifera of the Upper Miocene from some Italian sections and the problem of the lower boundary of the Messinian. Boll. Soc. Pal. Ital., 14:177-196.

Kastens, K. A., Mascle, J., et al., 1987. Proc. ODP, Init. Repts., 107: College Station, TX (Ocean Drilling Program).

Rehault, J. P., Kastens, K., Mascle, J., et al., 1987. ODP Leg 107 (Tyrrhenian sea): evolution of a very young margin. Terra cognita, 7 : 243-244.

Robertson, A.H.F., Hieke, W., Mascle, G., Kastens, K., Mascle, J., McCoy, F., McKenzie, J., Rehault, J. P., Sartori, R., et al., 1987. Tectonic and palaeooceanographic evolution of the Late Miocene-Recent Tyrrhenian sea (W Mediterranean) as a supra-subduction zone marginal basin in a continental collisional setting: ODP Leg 107. Terra cognita, 7:244.

Sartori, R., Mascle G., Kastens, K., Mascle, J., et al., 1987. Nature of the Tyrrhenian basements from ODP Leg 107 results. Terra Cognita, 7:244.

Tisseau, C., Rehault, J. P., and Foucher, J. P., 1987. Thermal regime of the Tyrrhenian sea: analysis of a profile from the margin towards the ocean basin. Terra cognita, 7:244.

Date of initial receipt: 15 January 1988

Date of acceptance: 10 February 1989 Ms 107B-193 
Table 2. Linear correlation coefficients (R) among the chemical data reported in Table 1.

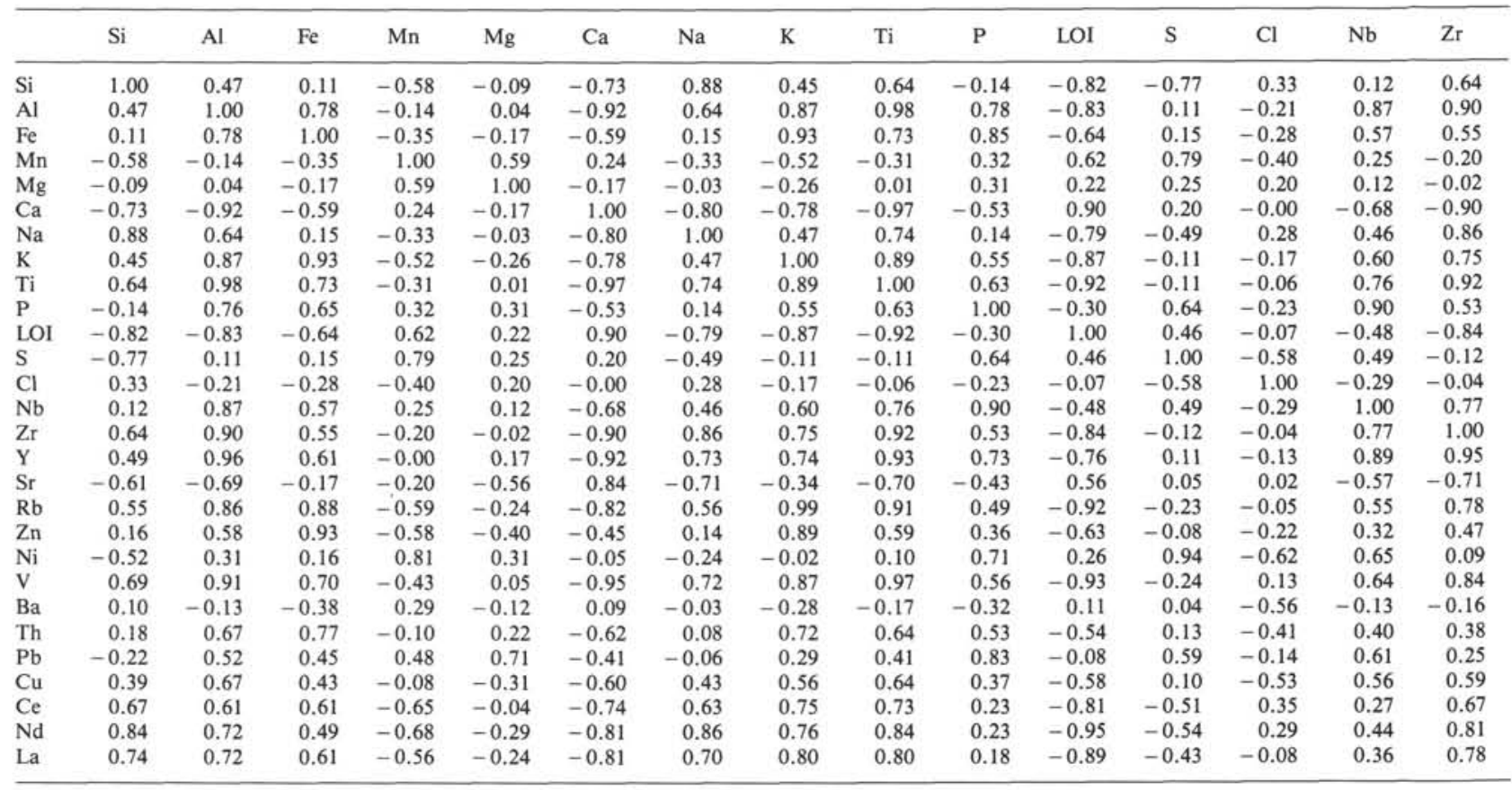

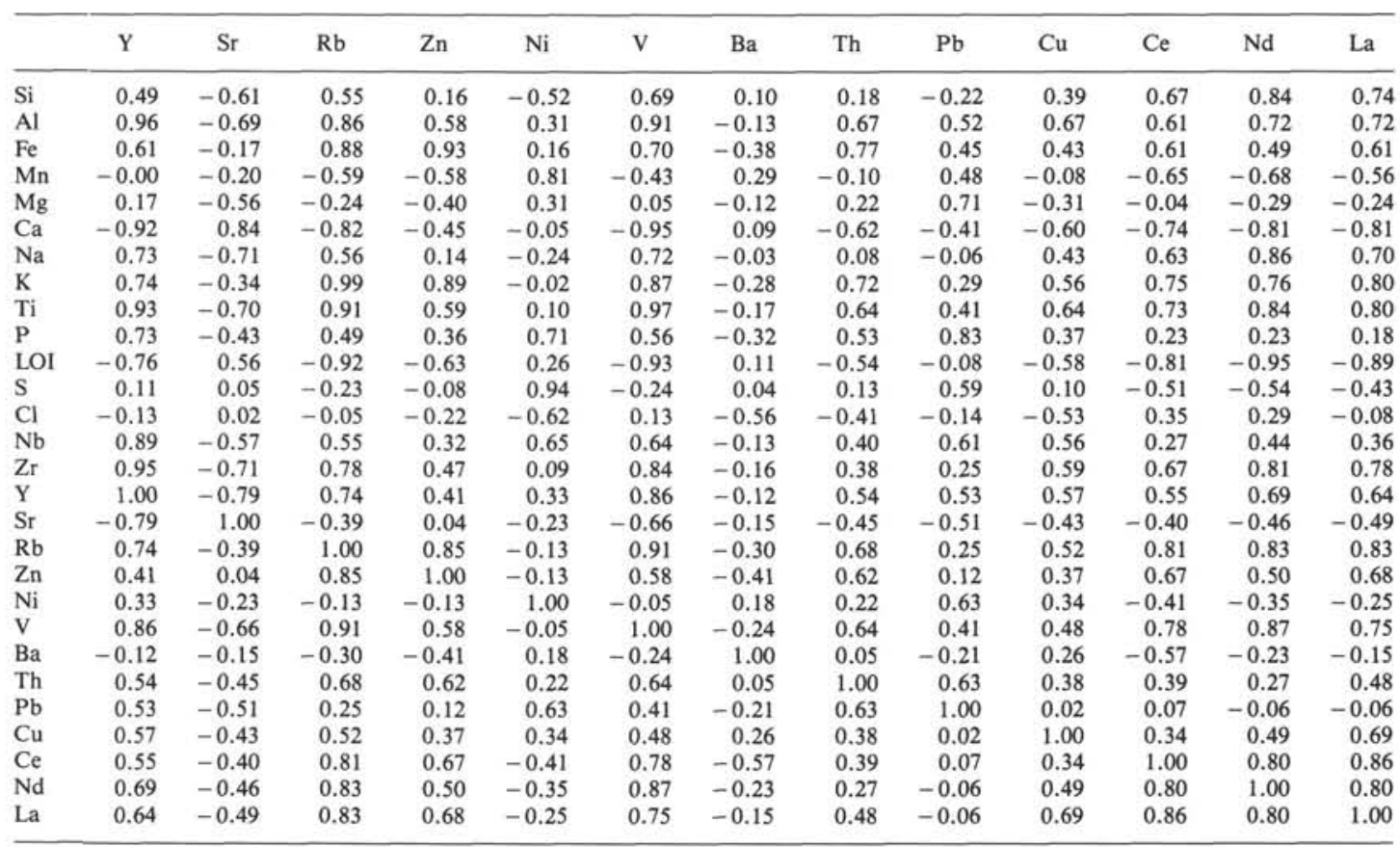


SAS

AVERAGE LINKAGE CLUSTER ANALYSIS

NAME OF OBSERVATION OR CLUSTER

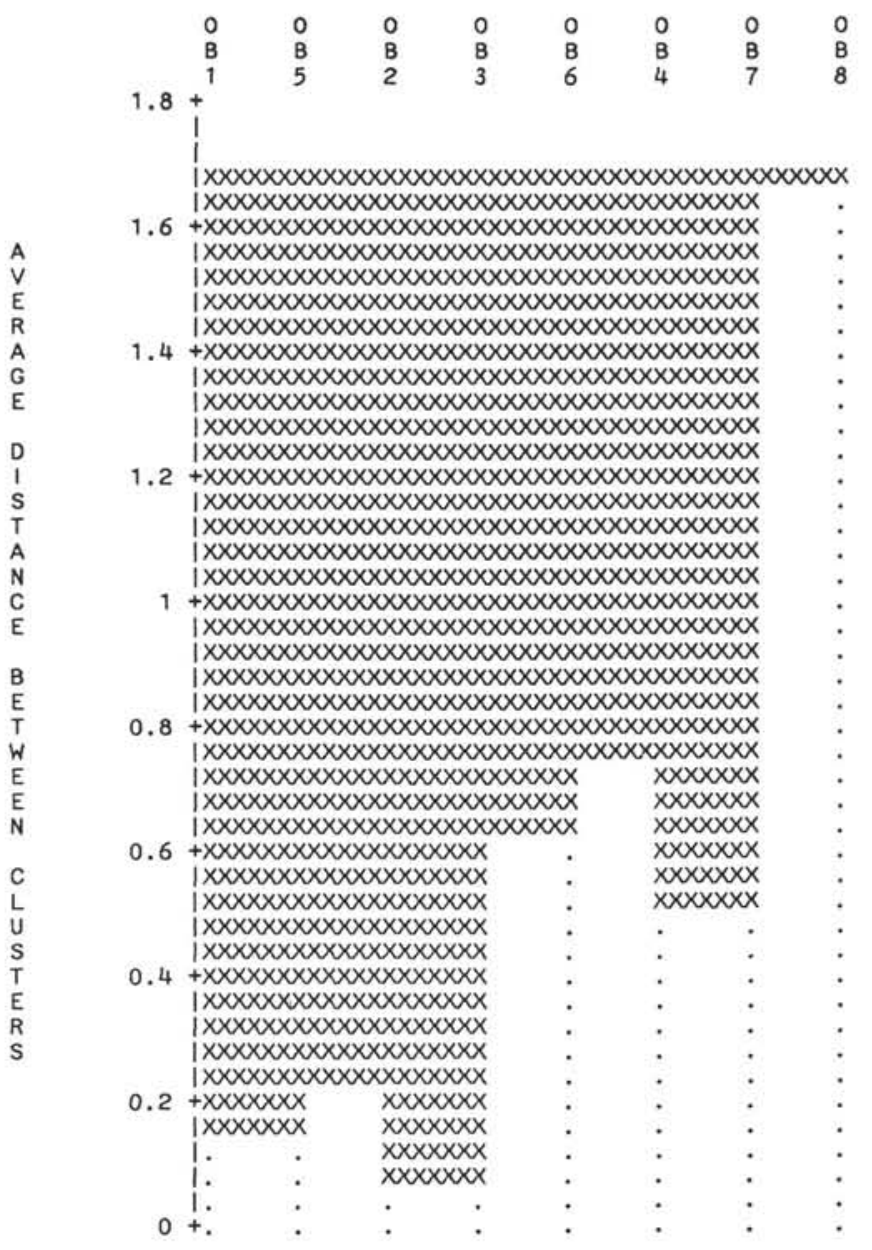

Figure 1. Average distance between clusters of the samples 1-8 in Table 1. 


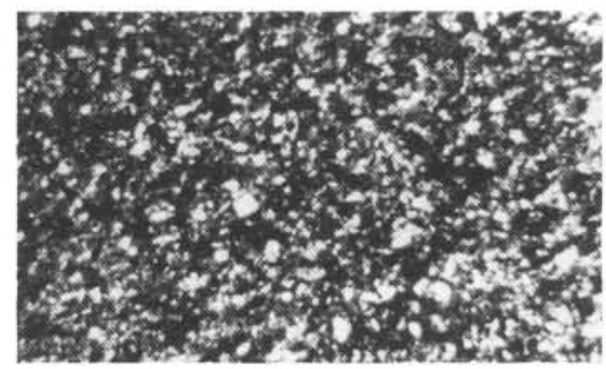

1

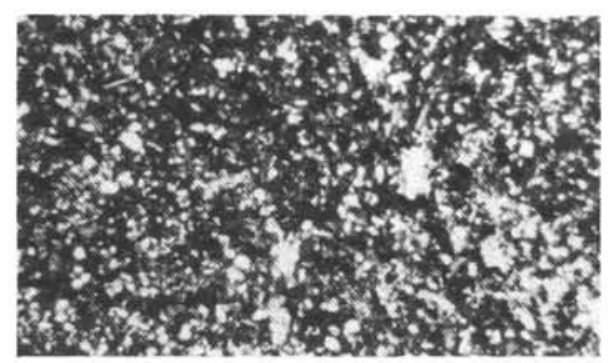

2

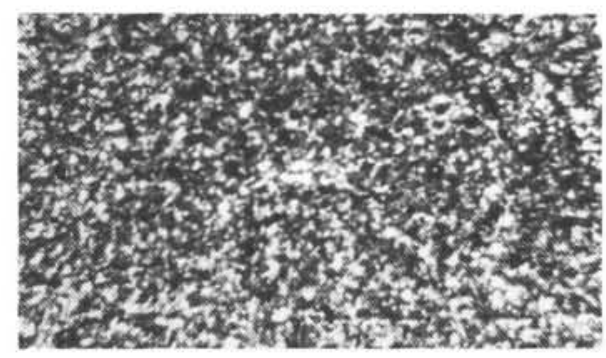

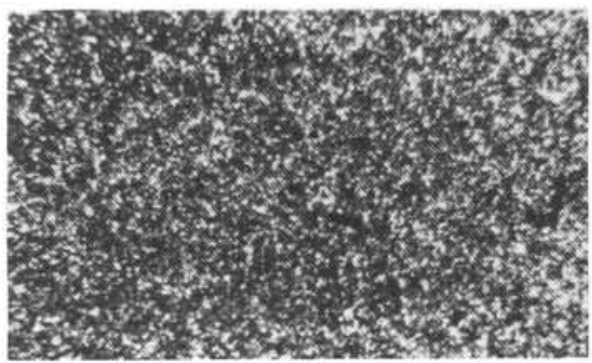

4

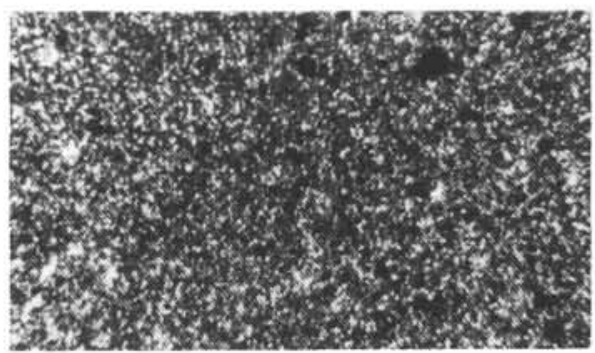

5

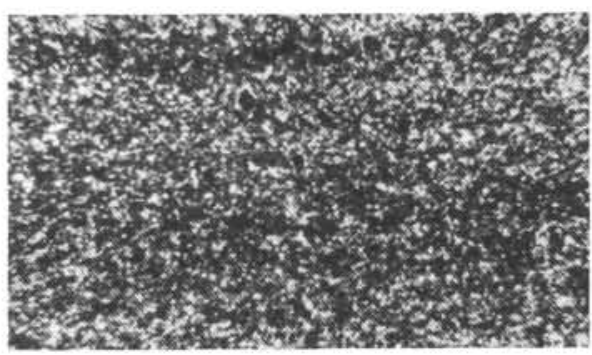

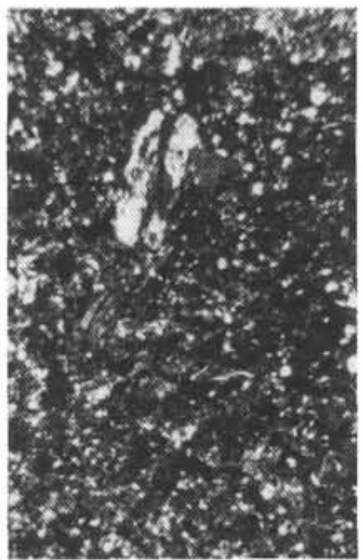

7

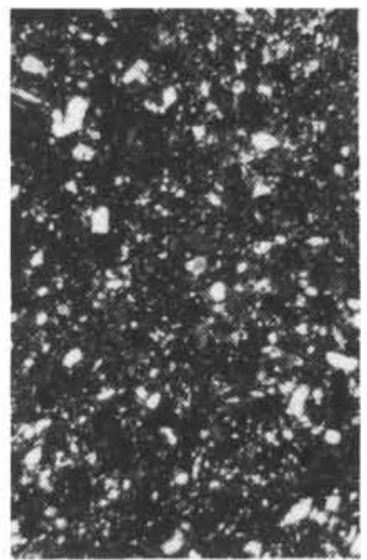

3

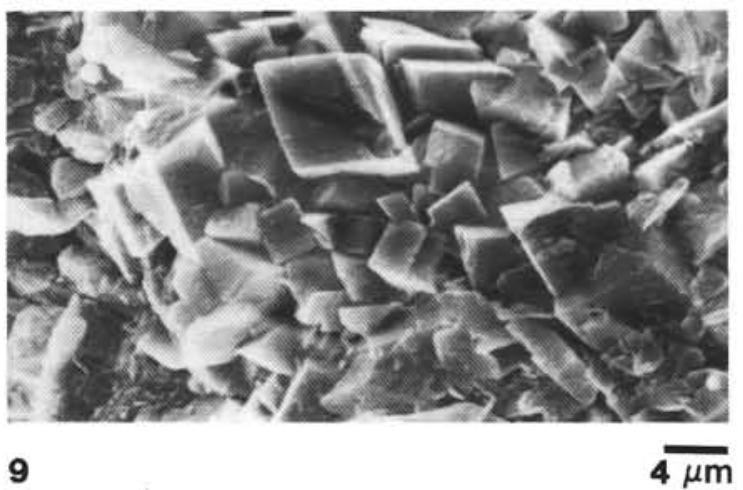

6

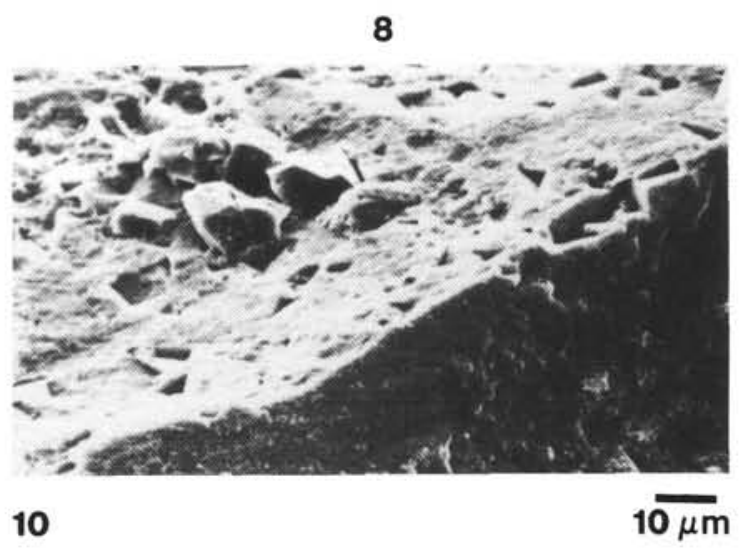

Plate 1. 1-8. Thin section photomicrographs showing textural features of the analyzed samples (magnification is $8 x$ ). 1. 107-652A-73R-01, 107$109 \mathrm{~cm}$. 2. 107-652A-73R-02, 049-052 cm. 3. 107-652A-73R-03, 043-046 cm. 4. 107-652A-74R-02, 117-119 cm. 5. 107-652A-74R-04, 105-107 cm. 6. 107-652A-74R-CC, 007-009 cm. 7. 107-654A-45R-06, 066-068 cm. 8. 107-654A-47R-01, 076-078 cm. 9. Scanning electron micrograph showing dolomite crystals from Sample 107-652A-73R-01, 107-109 cm. 10. Scanning electron micrograph of quartz grain (Sample 107-652A-73R$01,107-109 \mathrm{~cm}$ ) showing pitting from grain dissolution and overgrowth of calcite crystals. 